\title{
Hysteresis Analysis of Prestressed Brick Frame with Strawbale Masonry Infill Subjected to Seismic Loads
}

\author{
Adeola A. Adedeji ${ }^{1, *}$, Abiola Adedeji², Aminu Ibiyeye3 \\ ${ }^{1,2,3}$ Department of Civil Engineering, University of Ilorin, Ilorin, Nigeria \\ *aaadeji@unilorin.edu.ng
}

\begin{abstract}
This study looks at designing and evaluating strength of typha strawbale wall cross section rather than the assumption of edge column acting as axially loaded members that should resist all vertical members from the loads acting on the wall. Based on the aforementioned claim, the objective of this work is to provide the average design thickness for the cement-plastered typha strawbale that stiffens the prestressed brick frame. Data on strength and deformation of the structure are the input for the analytical models. Pseudo-dynamic earthquake response tests, of a one quarter (1/4) scale model low rise storeys prestressed brick frames stiffened with cement plastered strawbale masonry was conducted. The structure is idealized as plane frames. The analysis utilised the hysteresis models for members' models as timeindependent. The force-displacement relationship of the members' models has been evaluated by the approximate method on the basis of the material properties and structural geometry. A model was investigated with straw bale infill panel to determine the hysteretic parameters, stiffness deterioration and strength degradation due to seismic forces.

Keywords: seismic; masonry-infill; typha strawbale, finite element; degradation, brick
\end{abstract}

\section{Introduction}

A number of past studies ([1],[2],[3]) focused on evaluating the experimental behavior of masonry infilled frames to obtain formulations of limit strength and equivalent stiffness. A more rigorous analysis of structures with masonry infilled frames requires an analytical model of the force - deformation response of masonry infill. While a number of finite element models have been developed to predict the response of infilled frames ([4]. [5], [6]), such micro modeling is timeconsuming for analysis of large structures. Alternatively, a macro model allows treatment of the entire infill panel as a single unit.

Saneinejad and Hobbs [7] developed a method based on the equivalent diagonal strut approach for the analysis and design of frames with masonry infill walls subjected to in-plane forces. The UBC required that the shear walls acting independently of the ductile moment-resisting portions of the frame shall resist total required seismic forces. It is also required that design force distributions along elevations of the structure for both axial- flexural and shear design shall be the same. It has been observed from the research carried out by [8] the UBC later claim could be realized by shear design based on calculation that demands that consider actual flexural capacity of the walls. The actual contribution of the edge members (columns and beams) panel $\mathrm{RC} /$ prestressed concrete should be considered in evaluating available shear strength. Therefore the study has recommended that in designing and evaluating of strength of wall, cross section should be considered rather than the assumption of edge column acting as axially loaded members that should resist all vertical members from the loads acting on the wall.

Based on the aforementioned claim, the objective of this paper was to provide the average design thickness for the cement-plastered strawbale stiffens the prestressed burnt-brick frame. Data on strength and deformation of the structure are the input for the analytical models. The plastered strawbale wall was connected to the prestressed brick frame with mortar (1:6 cement-sand mix) to constitute a simple support.

\section{Modelling of Structural Members}

\subsection{Frame: Beam and Column Members}

A one-dimensional model was used for beam and column in this paper. The beam or column member was idealized as a perfectly idealized elastic massless line element with two nonlinear rotational springs at the two ends. The model could have two rigid zones outside the rotational spring.(Fig. 1).

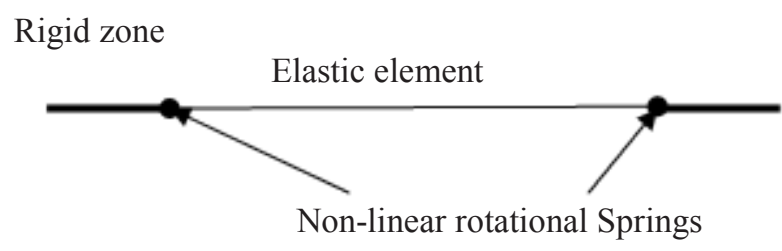

Fig. 1. One-dimensional model for beam and column

\subsection{Analytical Model of strawbale Infill}

Shear walls can be idealized as (a) an equivalent column taking flexural and shear deformation into account, (b) a braced frame in which the shear deformation is represented by deformation of diagonal elements, where the structural deformation is by the deformation of vertical element and (c) short line represent along the height with each short segment with hysteretic characteristics. These models have advantages and disadvantages. In most cases the horizontal boundary beams are assumed to be rigid. 
The proposed analytical model assumes that the contribution of the straw bale wall infill panel to the response of the infilled frame can be modelled by replacing the panel by a system of two diagonal straw bale wall compression struts. Since the tensile strength of masonry is negligible, the individual straw bale strut is considered to be in effective in tension. However, the combination of both diagonal struts provides a lateral load resisting mechanism for the opposite lateral directions of loading. The lateral force-deformation relationship for the structural straw bale infill panel is assumed to be a smooth curve bounded by a bilinear strength envelope until the yield force and then on a post yield degraded stiffness until the maximum force is reached.

\section{2.1 Strawbale Wall as Infill Panel}

The use of strawbale infill for the construction of a building in place of conventional materials is its cheapness, availability and flexibility in terms of workability and strength.

Though the individual straw bale strut is considered to be in effective in tension, yet strawbale masonry has a high tensile strength. The load resisting mechanism of infill frames is idealized as a combination of moment resisting frame system formed by the frame and a pinjointed system formed by the strawbale. However, because of the absence of a realistic, yet simple analytical model, the plastered straw bales as infill panels might be neglected in the non-linear analysis of building structures. Such an assumption may lead to substantial inaccuracy in predicting the lateral stiffness, strength, and ductility of the structure.

Saneinejad and Hobbs [7] developed a method based on the equivalent diagonal strut approach for the analysis and design of steel or concrete frames with masonry infill walls subjected to in-plane forces. The method takes into account the elastoplastic behaviour of infilled frames considering the limited ductility of infill materials. The formulation provides only extreme or boundary values for design purposes. In the case of straw bale panel, the aspect ratio, shear stresses at the interface between the infill and frame, together with the frame strength were accounted for and the formulation expresses the boundary values for design purposes.

\section{Equivalent Strut Model}

The description, in brief, of the formulations for predicting the parameters of the strawbale infill-panel is presented in this section. Considering the straw-bale infilled frame as shown in Fig. 2, the maximum lateral force and corresponding displacement in the infill straw bale panel are considered.at lateral dimension of the wall panel for the masonry strength at the inclination of the diagonal strut to the horizontal at the shear strength $(\mathrm{V}=$ average of $0.347 \mathrm{~N} / \mathrm{mm}^{2}$ ), of straw bale wall. The area and length of the equivalent diagonal struts and are denoted as $A_{d}$ and $L_{d}$, respectively.

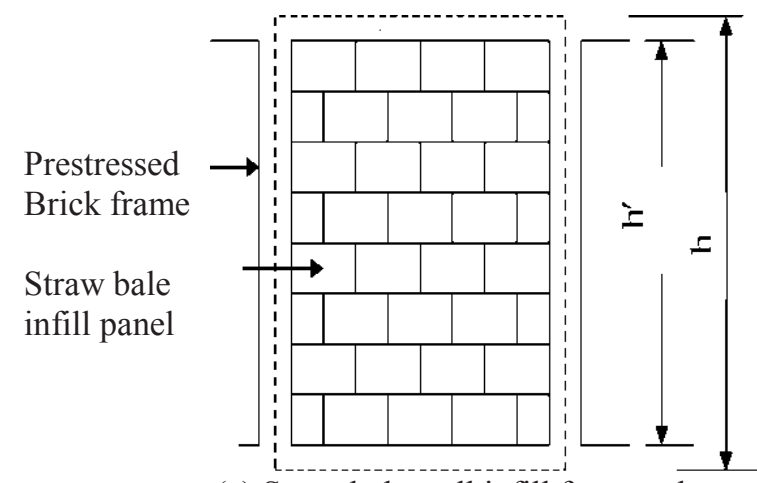

(a) Straw bale wall infill frame sub assemblage

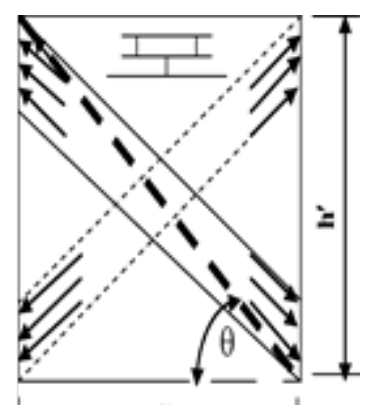

(b) Straw bale wall infill panel

Fig. 2. Wall equivalent diagonal strut

\subsection{Time-independent smooth hysteresis model}

A smooth hysteretic model proposed by [9] is used for the structural straw bale masonry infill panel. The model, which was developed based on the Bouc-Wen model for hysteresis behaviour furnishes a smooth hysteresis forcedisplacement relationship between force $\mathrm{V}$ and displacement $U$ is,

$$
\mathrm{V}_{\mathrm{i}}=\mathrm{V}_{\mathrm{y}}\left[\mathrm{am}+(1-\mathrm{a}) \mathrm{Z}_{\mathrm{i}}\right]
$$

Where ductility is calculated as $\mathrm{Ui} / \mathrm{Uy}$, subscript $\mathrm{i}=$ instantaneous values, subscript $\mathrm{y}=$ yield values, and $\mathrm{Z}=$ hysteretic component determined by solving the following differential equation by [10] as;

$$
d Z i=\left[a_{e f f}-1 Z_{i} \operatorname{In}\left[p \operatorname{sgn}\left(d_{m} Z\right)+y\right]\right] d i
$$

where signum function $\operatorname{sgn}(\mathrm{x})=1$ for $\mathrm{x}>0$ and $=-1$ for $\mathrm{x}<0 ; \mathrm{a}_{\mathrm{eff}}=3$, and $\mathrm{y}=$ constants that control the shape of the generated hysteretic loops (Assumed values $a_{\text {eff }}=$ 1 , and $p=y=0.5$. At $x=0$, the effect of cyclic loading is neglected) and $n$ controls the rate of transition from the elastic to yield state.

\subsection{Stiffness Decay and Strength Degradation}

The yielding system in general is the loss of stiffness due to deformation beyond yield point. The stiffness decay is incorporated directly in the hysteretic model by including the control parameter $r$ ) in equation (1) for hysteretic parameter $\mathrm{Z}$ in which 77 is obtained by pivotal deterioration method [11]. Degrading systems such as 
straw bale wall infill panels will also exhibit loss of strength in the inelastic range. The strength deterioration is modelled by reducing the yield force $V_{y}$ from the original value $\mathrm{V}_{\text {yo }}$ at each step $\mathrm{k}$,

$$
\mathrm{V}_{\mathrm{yk}}=\mathrm{V}_{\mathrm{yk}}(1-\mathrm{DI})
$$

in which DI $=$ cumulative damage parameter dependent on the maximum attained ductility, $\mathrm{I}_{\max }$, and the cumulative energy dissipated $[11,12,13]$.

\subsection{Cracking slip model}

Opening and closing of masonry cracks resulting in the pinching of hysteresis loops is a commonly observed phenomenon in masonry structural systems subjected to cyclic loading. The concept of slip lock element proposed by [9] was adopted in this study to formulate a hysteretic model. A slip-lock element is incorporated in series so that displacement ductility $\mathrm{j}_{\mathrm{u}}=\mathrm{j}_{\mathrm{UJ}}+\mathrm{j}_{\mathrm{u} 2}$, with the smooth degrading element.

\section{Experimental Tests}

\subsection{Tested Structure and properties of materials}

The tested structure represented a three-storey one-bay (span prestressed concrete ductile moment resisting frame filled with straw bale masonry), built at a scale of $1 / 4$. The overall geometry of the test structure is depicted in Fig. 3. Analytical example was carried out for a full scale version of the test structure and all pertinent quantities were scaled using the length factor of 0.25 . Each tested structure consists of strawbale wall (made of $127 \times 78 \times 61 \mathrm{~mm}^{3}$ unit size; elephant grass bale plastered with 1: 6 cement-sand mix ratio; average density of 2200 $\mathrm{kg} / \mathrm{m} 3 ; 12 \%$ absorption and moisture content of 3.61 . Its average compressive and flexural strengths are 2.83 and $1.56 \mathrm{~N} / \mathrm{mm}^{2}$ ) respectively) whose principal plane was parallel with the direction of the input motion. Design gravity loads comprised of $70 \mathrm{kN}$ (self weight and live load). Seismic design effects were determined using modal spectral analysis. The design spectral ordinates were set so that the first-mode shear base was equal to the design base shear required by the UBC 1982 for a ductile moment-resisting space frame. Also, the response spectrum was selected to reflect soil condition that superseded by a layer of sandy soil. Earthquake design actions were determined with a three dimensional elastic analysis model based on the cross section of columns and beams.

The three dimensional structure was idealized as a pseudo-three-dimensional model in which only the planar modes of the main structural systems (walls and frames) were considered. The considerations of stiffness and strength of frame elements perpendicular to the plane of the transverse walls and frames were not considered. Perfect base fixity of the frames was assumed. Horizontal floor level responses have been recoded in lateral and main direction. At $3.2 \mathrm{~m} / \mathrm{s}^{2}$, the structure did not increase its response. The maximum base shear of $129 \mathrm{kN}$ is obtained at the roof displacement of $12.3 \mathrm{~mm}$.

- The input signals to the shaking table modelled accelerated history for uniaxial tests are as indicated in Table 1 with a total of four earthquake records. These values were used as input ground motions in the dynamic analysis. These values are notations used for individual ground motion, the components of earthquake motion record, peak ground acceleration $\left(\mathrm{a}_{\mathrm{eff}}\right)$ in terms acceleration due to gravity $(\mathrm{g})$, peak ground velocity $\left(\mathrm{v}_{\mathrm{g}}\right)$, significant duration of the accelerogram $\left(\mathrm{t}_{\mathrm{SD}}\right)$ and the normalized characteristics intensity (In).

Table 1 Characteristics of selected input earthquake

\begin{tabular}{|l|l|c|c|c|c|}
\hline $\begin{array}{l}\text { Ground } \\
\text { motion }\end{array}$ & Notation & $\begin{array}{c}\text { Peak } \\
\text { ground } \\
\text { acceleration } \\
\left(\mathrm{a}_{\text {eff }}\right)\end{array}$ & $\begin{array}{c}\text { Peak } \\
\text { ground } \\
\text { velocity } \\
\left(\mathrm{vg}_{\mathrm{g}}\right) \mathrm{m} / \mathrm{s}\end{array}$ & $\begin{array}{c}\text { Signi- } \\
\text { ficant } \\
\text { duration } \\
\left(\mathrm{t}_{\mathrm{SD}}\right), \mathrm{s}\end{array}$ & $\begin{array}{c}\text { normalized } \\
\text { characteristi } \\
\text { cs intensity } \\
\left(\mathrm{I}_{\mathrm{n}}\right)\end{array}$ \\
\hline El Centro & ELCENT & $0.35 \mathrm{~g}$ & 0.34 & 24 & 2.66 \\
\hline Haruka-oki & HARU & $0.42 \mathrm{~g}$ & 0.46 & 6 & 2.12 \\
\hline Silmar & SYLM & $0.84 \mathrm{~g}$ & 0.61 & 47 & 1.71 \\
\hline Hacinohe & HACH & $0.23 \mathrm{~g}$ & 0.34 & 28 & 1.52 \\
\hline
\end{tabular}

\section{Typical Analysis Example}

\subsection{Sections properties}

Beam and column sectional area are shown in Fig. 6 . Second moment of area $\left(\mathrm{I}_{\mathrm{b}}\right)=2.278 \times 10-3 \mathrm{~m} 4(\mathrm{Ic})=$ $6.75 \times 10-4 \mathrm{~mm} 4$ respectively. The straw bale wall is measured acting as diagonal members of the frame in this analysis. It acts as a stiffening element and the area and length of the equivalent diagonals are as calculated below, Ld equivalent diagonal strut (Fig. 3)., $\mathrm{Ad}=$ $14235.0 \mathrm{~mm} 2.6681 .6 \mathrm{~mm}$ and area of

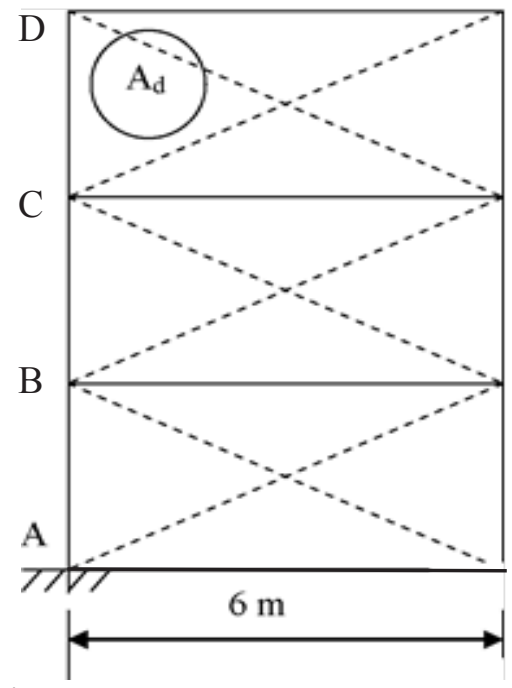

Beam section: $300 \mathrm{~mm} 450 \mathrm{~mm} \mathrm{~T}$

Column section: $300 \mathrm{~mm} 450 \mathrm{~mm}$

Fig..3. A three-storey building

\subsection{Earthquake Analysis and Loading}


For the absorption and dissipation of the energy through its motion, the frame of the building must be sufficiently ductile. For calculating ductility and other parameters it is assumed that the tests were entered to the ductile mode. It is assumed that during a strong ground motion the inertial of a building results in a horizontal shear force at the base and proportional to the weight of the building and the imposed ground motion, so that:

$$
\mathrm{VD}=\mathrm{C}_{\mathrm{s}} \mathrm{Mg}
$$

where $\mathrm{VD}=$ total dynamic base shear, $\mathrm{M}=$ total mass of the building and its contents $(\mathrm{kg}), \mathrm{g}=$ acceleration due to gravity, $\mathrm{C}_{\mathrm{s}}=$ seismic coefficient, $\mathrm{a}_{\mathrm{eff}}=$ dependent effective peak acceleration, $\mathrm{S}=$ seismic response factor, $\mathrm{R}=$ factor related to ductility of structure or force reduction factor, and $\mathrm{In}=$ normalized characteristics intensity. A good example of the seismic record characteristics is given by Moroni et al (1996) from 1985 Chilean earthquake. Assumed for the prestressed brick frame is the ductility factor $\mathrm{R}=5$ (braced frame, with effective peak acceleration aeff $=0.1-0.2 \mathrm{~g}$, seismic response factor $\mathrm{S}=2$ and the intensity factor $=$ 1 , so that the seismic coefficient $\mathrm{Cs}=0.04$. The total design base shear is $143.3 \mathrm{kN}$.. The lateral forces on the building are distributed over its height accordingly. The sum of the lateral forces is equal to the total base shear. The lateral forces on the building frame are shown in Table 2.

Table 2 Seismic forces on Building frame

\begin{tabular}{|l|c|c|}
\hline Storey level & $\begin{array}{c}\text { Equivalent lateral } \\
\text { force }(\mathrm{kN})\end{array}$ & $\begin{array}{c}\text { Equivalent } \\
\text { lateral shear }\end{array}$ \\
\hline Roof & 41.45 & 41.45 \\
2 & 71.65 & 113.10 \\
1 & 143.3 & 256.40 \\
\hline Total dynamic & & 256.4 \\
\hline
\end{tabular}

The maximum lateral force and corresponding displacement in the infill straw bale panel are as follows: At $32^{\circ}$ at $\mathrm{V}_{\mathrm{m}}+\left(\mathrm{V}_{\mathrm{m}}\right)=14486 \mathrm{~N}$, while the corresponding displacement $\mathrm{U}_{\mathrm{m}}+\left(\mathrm{U}_{\mathrm{m}}\right)=23.6 \mathrm{~mm}$. The initial stiffness Ko of the infill panel is estimated $K_{o}=1227.63 \mathrm{~N} / \mathrm{mm}$, the lateral yield force and displacement of the infill panel is $14193.4 \mathrm{~N}$ and $\mathrm{U}_{\mathrm{y}}+\left(\mathrm{U}_{\mathrm{y}-}\right)=11.7 \mathrm{~mm}$. Using different straw bale thickness, the result of the analysis for the stiffness deterioration and shear decay are shown in CASES II to IV.

CASE II, $\mathrm{t}=275 \mathrm{~mm}, \quad$ Ad $=13048.8 \mathrm{~mm}^{2}, \mathrm{~V}_{\mathrm{m}}=$ $13279.2 \mathrm{~N}, \mathrm{U}_{\mathrm{m}}=23.6 \mathrm{~mm}, \mathrm{~K}_{\mathrm{O}}=1125.4 \mathrm{~N} / \mathrm{mm}, \mathrm{V}_{\mathrm{y}}=$ $13145.1 \mathrm{~N}, \mathrm{U}_{\mathrm{y}}=11.7 \mathrm{~mm}$. The result of the analysis is shown in Table.2 At the instantaneous value 6, other cases (CASES III and IV) with varying wall thicknesses (t) are:

CASE III at $\mathrm{t}=250 \mathrm{~mm}$,

$\mathrm{A}_{\mathrm{d}}=11862.53 \mathrm{~mm}^{2}, \mathrm{~V}_{\mathrm{m}}=12071.9 \mathrm{~N}, \mathrm{U}_{\mathrm{m}}=23.6 \mathrm{~mm}$, $\mathrm{K}_{\mathrm{o}}=1023.05 \mathrm{~N} / \mathrm{mm}$, and $\mathrm{V}_{\mathrm{y}}=11949.9$

$\mathrm{N}, \mathrm{Uy}=11.7 \mathrm{~mm}$.

CASE IV, $\mathrm{t}=200 \mathrm{~mm}$,
$\mathrm{Ad}=10961.62 \mathrm{~mm}^{2}, \mathrm{~V}_{\mathrm{m}}=11155.2 \mathrm{~N}, \mathrm{U}_{\mathrm{m}}=23.6 \mathrm{~mm}$, $\mathrm{K}_{\mathrm{o}}=945.36 \mathrm{~N} / \mathrm{mm}$ and $\mathrm{V}_{\mathrm{y}}=11042.5 \mathrm{~N}$, $\mathrm{Uy}=11.7 \mathrm{~mm}$.

\subsection{Deflection check}

Maximum deflection of masonry wall is $24 \mathrm{~mm}$. This value is greater than $23.7 \mathrm{~mm}$ that was obtained in the analysis. Thus, the maximum deflection of the straw bale infill is less than the maximum allowed for masonry walls with the same dimensions $(6.000 \mathrm{x}$ $3.500 \mathrm{~m})$.

Table 3. Observed and measured response maxima for base isolated motion (Table acceleration $=1.07 \mathrm{~m} 2 / \mathrm{t}$ )

\begin{tabular}{|l|c|c|c|c|c|}
\hline Response & $\begin{array}{c}\text { Peak } \\
\text { accelera } \\
\text { tion }\end{array}$ & $\begin{array}{l}\text { Base } \\
\text { shear } \\
\mathrm{kN}\end{array}$ & $\begin{array}{c}\text { Total } \\
\text { weight of } \\
\text { the } \\
\text { structure } \\
\mathrm{kN}\end{array}$ & $\begin{array}{c}\text { Base } \\
\text { moment } \\
\mathrm{kNm}\end{array}$ & $\begin{array}{c}\text { Roof } \\
\text { displaceme } \\
\text { nt Mm }\end{array}$ \\
\hline $\begin{array}{l}\text { Observed } \\
\text { (prototype) }\end{array}$ & 0.58 & 129 & 210 & 95.8 & 12.3 \\
\hline Calculated & 0.1 & 143 & 365.62 & 158.6 & 23.6 \\
\hline
\end{tabular}

\subsection{Dynamic response results}

At calculated $Z=1$, the stiffness decay is incorporated in the hysteretic model by including the control parameter $\mathrm{T}]$ for the hysteretic parameter (r)i $>1.0)$. The default value of $S k=5$ is recommended. The results in Table 4 shows a typical example of iteration of dynamic response characteristics from the analysis are as for 200 and 250 only.

Table 4 Dynamic response characteristics of straw bale infill thickness $(\mathrm{t})=200 \mathrm{~mm}$

\begin{tabular}{|l|c|c|c|c|c|}
\hline $\begin{array}{l}\text { Dis- } \\
\text { placemen } \\
\mathrm{t}\left(\mathrm{U}_{\mathrm{i}}\right)\end{array}$ & $\begin{array}{l}\text { Ductilit } \\
\mathrm{y}(\mathrm{H} \underline{\mathrm{i}})\end{array}$ & $\begin{array}{l}\text { Control } \\
\text { values } \\
\left(\mathrm{r} \mathrm{j}_{\mathrm{i}}\right)\end{array}$ & $\begin{array}{l}\text { Hysteretic } \\
\text { parts }(\mathrm{dZ})\end{array}$ & $\begin{array}{l}\text { Lateral } \\
\text { force } \\
\left(\mathrm{V}_{\mathrm{i}}\right), \mathrm{N}\end{array}$ & $\begin{array}{l}\text { Shear } \\
\text { decay } \\
\left(\mathrm{V}_{\mathrm{m}}-\mathrm{V}_{\mathrm{i}}\right),\end{array}$ \\
\hline 11.7 & 1.0 & 1 & 1 & 11042.5 & 112.70 \\
\hline 11.8205 & 1.0103 & 0.9983 & 1.0017 & 11.062 .22 & 92.98 \\
\hline 11.9210 & 1.0189 & 0.9969 & 1.0031 & 11078.66 & 76.54 \\
\hline 12.0045 & 1.0260 & 0.9957 & 1.0043 & 11092.32 & 62.88 \\
\hline 12.0737 & 1.0319 & 0.9948 & 1.0053 & 11103.64 & 51.56 \\
\hline 12.1311 & 1.0368 & 0.9940 & 1.0061 & 11113 & 42.20 \\
\hline 12.1782 & 1.0409 & 0.9933 & 1.0067 & 11120.72 & 34.48 \\
\hline 12.2171 & 1.0442 & 0.9928 & 1.0073 & 11127.09 & 28.11 \\
\hline 12.2491 & 1.0469 & 0.9923 & 1.0077 & 11132.33 & 22.87 \\
\hline 12.2754 & 1.0492 & 0.9920 & 1.0081 & 11136.64 & 18.56 \\
\hline 12.971 & 1.0510 & 0.9917 & 1.0084 & 11140.13 & 15.03 \\
\hline 12.3148 & 1.0526 & 0.9914 & 1.0087 & 11143.08 & 12.12 \\
\hline
\end{tabular}

Other dynamic response results for $\mathrm{t}$ (thickness) $=275$ and 300 are not shown here, but are represented in the graphical forms. The strength deterioration is modelled by reducing the yield force $\mathrm{V}_{\mathrm{y}}$ from $\mathrm{V}_{\mathrm{yo}}$ at each step $\mathrm{k}$.

\section{Results and Discussion}

It was observed, from the result of the analysis, that the maximum lateral force the straw bale infill can be subjected to increases with the thickness of the infill 
panel. For thickness of $200 \mathrm{~mm}, \mathrm{~V}_{\mathrm{m}}=11155.2 \mathrm{~N}$; for $\mathrm{t}=$ $250 \mathrm{~mm}, \mathrm{~V}_{\mathrm{m}}=12071.9 \mathrm{~N}$; for $\mathrm{t}=275 \mathrm{~mm}, \mathrm{~V}_{\mathrm{m}}=13279.2 \mathrm{~N}$ and for $\mathrm{t}=300 \mathrm{~mm}, \mathrm{~V}_{\mathrm{m}}=14486 \mathrm{~N}$. Also, the stiffness and strength (hysteretic properties) of the straw bale wall infill decreases after the yield force. The yield force $\left(\mathrm{V}_{\mathrm{y}}\right)$ being $14193.4 \mathrm{~N}$ for $\mathrm{t}=300 \mathrm{~mm} ; 13145.1 \mathrm{~N}$ for $\mathrm{t}=275 \mathrm{~mm}$; $11949.9 \mathrm{~N}$ for $\mathrm{t}=250 \mathrm{~mm}$ and $11042.5 \mathrm{~N}$ for $\mathrm{t}=200 \mathrm{~mm}$. The maximum deflection of the infill was obtained to be $23.7 \mathrm{~mm}$, which was less than the maximum $24 \mathrm{~mm}$ specified for masonry infill walls. Also, it was found out that the hysteretic parameters deteriorate at a rate proportional to the thickness of the infill pane

Deflection (U,mm)

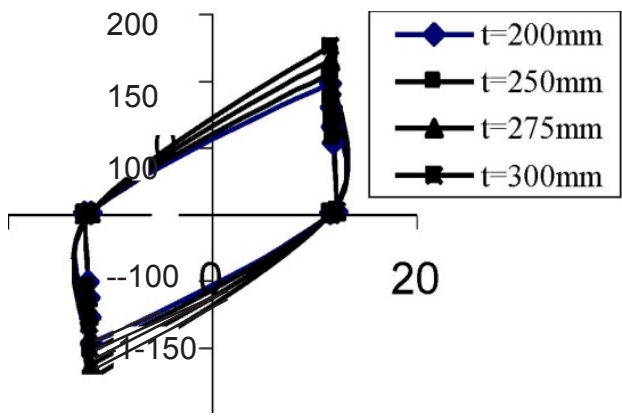

Fig. 4 Force-displacement relationship for strawbale infill (at $\mathrm{t}=200$ to $300 \mathrm{~mm}$ )

Deflection (U,mm)

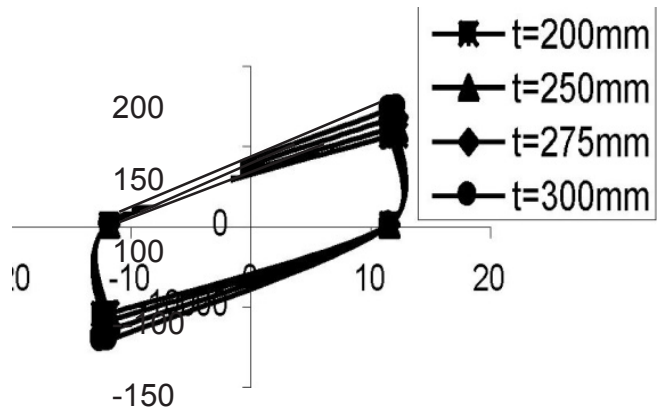

Fig. 5 Hysteresis curve with stiffness decay

Deflection (U,mm)

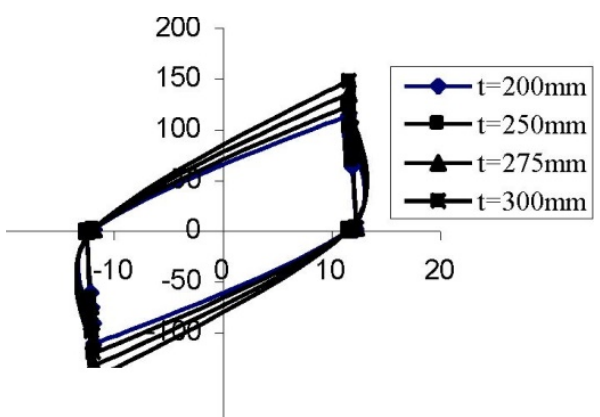

Fig. 6 Hysteresis curve with strength degradation

\section{Concluding Remarks}

The use of straw bale wall as an infill panel for the proposed hysteretic model can compete effectively with other conventional materials, such as earthwall (Adedeji, 2002), since its maximum deflection Um, is less than that specified for masonry walls. Though a perfect base fixity of the frames was assumed, the structure did not increase its response at $3.2 \mathrm{~m} / \mathrm{s}^{2}$. The maximum base shear of $129 \mathrm{kN}$ is obtained at the roof displacement of $12.3 \mathrm{~mm}$. these are far less values than the analysis results. The computed force-deformation response can be used to assess the overall structural damage and its distribution to a sufficient degree of accuracy.The structural materials characteristics were nominal values and may be different from the prescribed values. Such characteristics of materials for further analysis should be based on the confined and unconfined prestressed concrete.

\section{References}

1. R. E. Klinger and Bertero, V. V. Earthquake resistance of infilled frames, Journal of Structural Engineering, ASCE.104 (6), (1978),

2. V. V. Bertero and S. Broken, Infills in Seismic resistant building. Journal of Structural Engineering., ASCE. 109 (6): 1337-1361. (1983).

3. J. B. Mander and B. Na . Seismic resistance of brickinfilled steel frames with and without retrofit, The masonry J. 12 (2): 24-37. (1994).

4. M. Dhanasekar and A. W. Page, The influence of brick masonry infill properties on behaviour of infilled frames, Proc, Instin. of Civ. Engrs., London England, Part 2. 593-605 (1986).

5. Morom Mosalam, K.M. (1996). Modelling of the non-linear Seismic behaviour of gravity load designed infilled frames, 1995 EERI student Paper, Los Angeles, Calif. 1788. (1996).

6. P. K. Malnotra, Cyclic demand spectrum. Earthquake Engineering and StructuralDynamics, (31):14411457. (2002).

7. N. Buffalo, N. Y. Saneinejad, A., and Hobbs, B. Inelastic design of infilled frames. Journal of Structural Engineering. ASCE, 121 (4): 634650.(1995).

8. E. Ahmet., Aktan, M., Vitelmo, V and Bertero, E., Seismic response of $\mathrm{R} / \mathrm{C}$ frame-wall structures, Journal of Structural Engineering, 111(8), 1803 1821. (1984).

9. T. T. Berber and Noori, M. N.,. Random Vibration of degrading pinching system, Journal of Engineering Mech, ASCE 11(8): 1011-1026. (1985).

10. A. Madan, Reinhorn, A.M, Mander, J.B, Modeling of masonry infill panels for structural analysis, Journal of Structural Engineering, ASCE 123(10), (1997). (1997).

11. A. M. Rein, A. M., Madan, A.,Valles, R. E., Reichman, Y and Mander, J. B., Modelling of masonry infill panels for structural analysis, NCEER-95-0018, Nat.Centre of Earthquake Engineering, New York, (1995).

12. A. A. Adedeji, Hysteresis analysis of framed structures stiffened with earth wall infill subjected to seismic Impact, Conference Proc. SUSI-2002, UK. (2001) 
13. A. Adedeji, Analytical approach to framed structures stiffened with earth wall infill subjected to seismic loads, LAUJET Journal, 1(1).(2003). 